\title{
"Miradas cruzadas. Sobre la literatura italiana entre modernidad y posmodernidad", por Biagio D'Angelo y Assumpta Camps.
}

Fondo Editorial de la Universidad Católica

Sedes Sapientiae, Perú, 2002, 182 págs.

Reseña: Adriana Crolla: "Cruce del binario

en los paradigmas literarios actuales".

Claudio Guillén propone en su último ensayo de literatura comparada que la revolución operada por el método comparatista sobre los paradigmas teórico-literarios de la tradición occidental (grandes autores, géneros, formas, temas, escuelas, movimientos y las continuidades singulares en cada sistema literario) es la de haber aprendido a hacer las pases con la historia y lo historiable, no ya entendido este último sólo como cronología o serie de individualidades sino como plural evolución de conjuntos. Porque si bien las lecturas críticas de los textos y de los marcos teóricos que permiten iluminarlos son imprescindibles, es importante saber descubrir y operar un necesario découpage, en la maraña inimaginablemente infinita de la literatura, reconociendo aquellas "provincias finitas de sentido" o "sistemas de tendencias" que, relacionados entre sí, construyen significaciones por medio no sólo de las analogías sino también de sus diferencias. "El comparatista suele utilizar sus especialidades o sus lenguas desde adentro, como enfoque habitual para el estudio de (...) las muchas moradas virtuales en que puede subdividirse, organizarse y manifestarse la literatura".

Los autores de este volumen han logrado no sólo encontrarse en el binario cruzado y especular de lecturas comunes sobre la literatura italiana en relación con la modernidad y su herencia cultural-ideológica en la actual era posmoderna, sino, lo que es más interesante, "en" y "por" el cruce del binario, superar lo inmóvil, lejano y cerrado mostrando que por los andenes literarios las paralelas pueden y deben tocarse. Y para ello recurren a E. Said, mediatizado por Guillén, quien los habilita a hablar de "literatura como un modelo 'supranacional' del polisistema cultural".

Biagio (Doctor en Literatura Comparada por la Universidad de Moscú y profesor de literatura italiana en Perú) y Camps (Doctora en Filología por la Universidad de Barcelona y actual profesora de Literatura italiana y traducción literaria en esa misma universidad) se reparten equitativamente los ocho ensayos que integran el volumen. Sus análisis, sin perder el eje propuesto en el subtítulo, explotan los contactos y los cortocicuitos, en un recorrido temporal y espacial a "contracorriente", de vecindades a veces desconocidas entre las voces y miradas convocadas.

Tabucchi, la problemática de la alteridad y el orientalismo dan pie no sólo a un sesudo análisis sobre la posición actual de Italia en el contexto internacional sino también a descubrir la presencia paradigmática de la modernidad baudeleriana en su narrativa. La representación de lo oriental en la literatura de viajes y la problemática multicultural se aúnan en sendos ensayos sobre la diversidad imagológica 
que un mismo espacio físico y cultural, la India, asume en la escritura de Alberto Moravia, Pierre Loti y Guido Gozzano. La extraña persistencia en la contemporaneidad de un mito homérico -Circe-, en la obra de los escritores Pavese y Cortázar, permite analizar la coetaneidad y, sin embargo, disimilitud de relecturas sobre un mismo mito. Las crisis de la subjetividad y el lenguaje en la estética posmoderna para leer en clave comparatista la estética teatral en Maiakovski y Pirandello, haciendo visible las líneas de filiación que ambos comparten y que confluyen en Dostoievski. Presencia de temas y motivos del simbolismo francés en la escritura de viaje y exilio de Dino Campana y last but not least, un particular análisis de los motivos órficos en la poesía de Clemente Rébora y Alejandra Pizarnik que habilitan al crítico descubrir en ambos claves místicas en el "ennui" desesperado de los poetas contemporáneos.

Uno de los ensayos tiene como prefacio una cita de Pierre Brunel que aúna el acto de viajar a las miradas del comparatista. Si todo viajero es un comparatista, todo comparatista es un viajero. Viajero de la mirada que circular, contacta y entrama. Los autores de este libro se propusieron experimentarlo y debemos reconocer que lo lograron.

${ }^{1}$ Guillén, C. (1998), Múltiples moradas, Barcelona, Tusquets. 